\title{
An Evaluative Study Of Primary Education In The Light Of Policies And Plans In Pakistan (1947 - 2006)
}

Shahida Parveen, UIER, Pir Mehr Ali Shah Arid Agriculture University Rawalpindi, Pakistan.

\begin{abstract}
The paper is based on a research conducted to evaluate primary education in the light of education policies and plans in Pakistan. This article discusses the objectives of primary education, and analyzes different education policies and plans regarding the achievements of objectives. Results revealed that the objectives of primary education were not fully achieved. The procedure of implementation of the policies and plans remained weak.
\end{abstract}

Keywords: Evaluative Study, Primary Education, Policies, Plans, Pakistan

\section{INTRODUCTION}

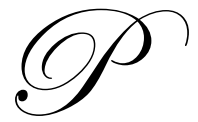

rimary education is the most important subsector of the entire educational system. It is considered to be investment in human capital as it builds human capability which is vital ingredient for national building. Khan (2002) argues that primary education can help in alleviating poverty by increasing income, improving health and nutrition and reducing fertility.

Education for an independent sovereign state is almost different from a dominated nation. Pakistan on coming to being inherited many problems; illiteracy the top most. Just after independence, in 1947, an All Pakistan Education Conference was convened. Need for the Universal Primary Education (UPE) was agreed to by the participants of the conference. The Education Policy 1972-80 reiterated free and universal primary education; financial constraints were the major hindrances to its success. Benchmarks of National Education Policy and Implementation Programme 1979 about primary education were curious, novel and innovative. Mosque Schools, Community Schools were the off shoots of the policy but couldn't be a success. The causes may be the planning mismatch, financial limitations, growing imports, decreasing exports, challenged GNP and population explosion.

A policy could only be a success when; the existing shortfalls are made the footing, the match with the resources is sought and the viable methods of implementing the policies are suggested and followed. Policies normally encompass the targets to be reached, lime light the gray areas, and the most tangible implementation strategies.

Since Independence studies have been conducted on different aspects of primary education. But perhaps no comprehensive study has so far been conducted in the area of Primary education, covering all the aspects i.e. curriculum, teacher training and examination system. Therefore, the study was undertaken to evaluate primary education in the light of education policies and plans in Pakistan. The study would be significant because of its following dimensions: the planning becomes true because of the doable tangible and practicable policies; the projects, plans and programmes emerge out of policies; and planning at the wider level need pre-conceived notions contentions and targets; all these are the parts of the policies. The study will help to eliminate the prevailing shortcomings and mistakes, if any, and to improve the primary education by assisting the decision makers, policy makers and planners to think in the right direction. 
In Pakistan various policies did come up that emphasized primary education but till now much more is needed to be done. The participation rate needs to be maximized, drop out is to be minimized, the curriculum is to be made more functional and of every day use, the quality of education is to be improved by improving the allied factors, training programmes need special match with the current coming up changes, the equity in terms of quality; and provision of resources has also been a matter of concern, the financial allocations and their proper utilization needs special care and attention. How far the policies and plans could be a success is a matter to ponder. Hence the study was undertaken. The main objectives of the study were: to analyze objectives of primary education in the light of education policies and plans since 1947; to examine the procedures of implementation of education policies and plans regarding primary education. The study was delimited to the government primary schools allover Pakistan.

\section{REVIEW OF LITERATURE}

\section{Proceedings of the Pakistan Education Conference, 1947}

According to Govt. of Pakistan (1947), the committee agreed on the following objectives: provision of free and compulsory primary education; opening of pre-primary schools and provision of proper training of teachers. Govt. of Pakistan (1956) introduced the First Five Year Plan (1955-60) in 1956. The plan noted that 50.3 percent of the children between the ages of 6-11 were in schools. The plan stated the objectives: the provision of universal free primary education, increase enrolment, improvement in the quality of education, provision of need-based curriculum; and training of teachers. Govt. of Pakistan (1960) analyzed that accomplishments were disappointing. No significant improvements were made. Enrolment did not increase to the extent expected.

\section{Report Of The Commission On National Education 1959}

Govt. of Pakistan (1960b) described that the National Education Commission was appointed in December, 1958. The commission recommended: the provision of compulsory primary education; ensure community participation; development of curriculum; provision of in-service teacher training and two years teacher training after matriculation. The Second Five Year Plan (1960-65) emphasized: to raise the enrolment; revise curricula; and in-service training of teachers (Govt. of Pakistan, 1960). The target of enrolment was fully achieved, free primary stage was introduced and programmes of in-service training of primary school teachers were started (Govt. of Pakistan, 1965). The curriculum committee was formed in early 1960 to prepare the curriculum, but the curriculum committee unfortunately, did not frame any syllabi for class I to V. (Govt. of Pakistan, 1966)

The Third Five Year Plan (1965-70) envisaged: to increase enrolment from forty five percent in 1965 to seventy percent in 1970; reduce dropout; and improve the quality of education. The plan realized that examination system encouraged memorization (Govt. of Pakistan 1965). The rate of implementation remained low (Govt. of Pakistan 1970b). Thirty seven percent of the enrolment target was achieved (Aziz, 1986).

\section{The New Education Policy 1970}

The policy and the Fourth Five Year Plan (1970-1975) remained unimplemented due to war with India.

\section{The Education Policy 1972-1980}

Govt. of Pakistan (1972) emphasized: the nationalization of private education institutions; provision of universal and free primary education; increase enrolment; provision of free textbooks; revision of curricula and teacher training courses; and replacement of annual examination with continuous evaluation. Govt. of Pakistan (1976) observed that in 1972, private institutions were nationalized. Nationalization did not result either in the expansion or qualitative improvement of education (Govt. of Pakistan, 1979). The period of 1972-77 was called non-planned period. In 1977, after thirty years of independence, the importance of curriculum revision was realized by the political government. Govt. of Pakistan (1977) asserted that the schemes of studies were finalized and revised curricula were introduced. In-service teacher training was improved. The curriculum for teachers training was 
changed and examination system was revised. Govt. of Pakistan (1978b) noted that the curriculum of teachers training programme was revised.

\section{National Education Policy And Implementation Programme 1979}

In 1978, the Fifth Five Year Plan (1978-1983) was introduced while the policy was introduced in 1979. The plan aimed at: universal enrolment by 1986-87; increase in participation rate from 54 percent to 68 percent by 198283; improvement in the quality of instruction and curricula; provision of free textbooks; extension of in-service training facilities; and reformation of examination system (Govt. of Pakistan, 1978a).

According to Govt. of Pakistan (1979), the policy objectives were: to attain universal primary education by 1986-87; improve the quality of education; supply free textbooks; review curricula; improve the quality of teacher education; train educational administrators and supervisors; and improve the examination system. The National Education Council was established to keep an eye on the implementation of educational programmes. Govt. of Pakistan (1980) described that new curriculum was introduced with emphasis on Islam and ideology of Pakistan. Inservice training was arranged. Govt. of Pakistan (1983a) further observed that the participation rate declined from 54 percent in 1977-78 to 48 percent in 1982-83.

The Sixth Five Year Plan (1983-88) emphasized: the universal primary education; increase in participation rate from 48 percent in 1982-83 to 75 percent in 1987-88; utilization of mosques to accommodate classes I to III; provision of separate girls schools; and redesigning of teacher education curricula (Govt. of Pakistan, 1983). Govt. of Pakistan (1988) noted that although the sixth plan achievements were lower than the targets, considerable progress was made in the education sector. Several innovative projects to improve the quality of education were launched on an experimental basis. Ahmed (1989) viewed that only 35 percent of the targets were achieved. The target of opening of girls primary schools could not be achieved. Jabeen (1990) analyzed that the participation rate at primary level was achieved by 64 percent against the target of 75 percent.

The Seventh Five Year Plan (1988-1993) envisaged: the universalization of primary education by 1992-93; improvement in the quality of education; legislation for compulsory primary education; improvement in textbooks; compulsory in-service training; and establishment of Educational Testing and Measurement Services (Govt. of Pakistan, 1988). Govt. of Pakistan (1993a) analyzed that some of the important policy initiatives proposed in the plan could not be implemented. About 3.1 million additional children (including 1.5 million girls) were enrolled at the primary level against the target of 4.6 million (including 2.7 million girls).

\section{National Education Policy 1992}

Within one year of the declaration of the policy, the political government was ousted. Therefore, it could not be implemented (Shah, 1998).

The Eighth Five Year Plan (1993-1998) emphasized: universal access to primary education; enrolment of additional 5.548 million children; increase participation rate; enactment and enforcement of compulsory primary schooling; encourage private sector; qualitative improvement of the curricula; reformation of teacher training curricula; enhancement of entry qualification of teachers and qualitative improvement of the examination system (Govt. of Pakistan, 1993). Govt. of Pakistan (1994) noted that a project was launched through distance education programme to train untrained teachers. Govt. of Pakistan (1996) further noted that in-service short term and log term training programmes were also conducted. Govt. of Pakistan (1998b) observed that Non-formal Basic Education schools were provided to achieve the target of Universal Primary Education. Social Action Programme for education was initiated. Community participation was started. The quality of education was improved and private sector was encouraged. Some of the targets remained unaccomplished, mainly due to financial constraints. Compulsory Primary Education Act could not be implemented. The target of increasing enrolment from 12.414 million to 17.962 million with a net increase of 5.548 million children, thereby raising the participation rate from 68.9 percent to 87.7 percent, remained unaccomplished. 


\section{National Education Policy 1998-2010}

Govt. of Pakistan (1998a) stated the objectives: to integrate primary and middle level education into elementary education; to enhance gross participation rate from existing 71 percent to 90 percent by the year 2002-03 and 109 percent by 2010; to reduce disparities; to introduce uniform curricula; to develop new and demanding curricula; to raise entry qualification of teachers; to reform examination system.

The Ninth Five Year Plan (1998-2003) emphasized: to achieve universal primary education by 2010; increase the participation rate for boys from 89 percent to 100 percent and for girls from 60 percent to 80 percent; expand the involvement of private sector in education; provide free textbooks to girls; ensure the quality of education; legislation for compulsory primary education; and develop curricula (Govt. of Pakistan, 1998b).

National Survey (Govt. of Pakistan, 1999) reported that private sector was involved for expansion of education. The curriculum was being revised. The revised curriculum was based on the needs of the society. Govt. of Pakistan (2000) observed that overall participation rate was 89 percent (boys 99 percent and girls 79 percent). Free textbooks were given to poor girl students of rural areas. Govt. of Pakistan (2001) further observed that the Ministry of Education initiated Education Sector Reforms (ESR) aimed at qualitative and quantitative improvement. National Survey (Govt. of Pakistan, 2002) observed that an ordinance for compulsory primary education was promulgated. The Ministry of Education had launched a project to give free textbooks initially in Islamabad Capital Territory. Govt. of Pakistan (2003) stated that National Education Assessment System (NEAS) was established. Govt. of Pakistan (2005) described that free textbooks were being provided.

Govt. of Pakistan (2006) concluded that the Gross Enrollment Rate (GER) for the primary schools (age 59) increased from 72 percent in 2001-02 to 86 percent in 2004-05. The Net Enrolment Rate (NER) was 42 percent in 2001-02 and had increased significantly to 52 percent in 2004-05. Two main indicators that show the changes in the primary schooling were Gross Enrollment Rate (GER) and Net Enrollment Rate (NER). The last four years had witnessed 14 percentage points increase in the gross primary enrollment which was more than 3 percentage point per annum increase on average. That increase from 72 percent in 2001-02 to 86 percent in 2004-05 was a result of targeted and resilient policies of the government.

\section{RESEARCH METHODOLOGY}

157,200 primary schools $(112,800$ boys and 44,400 girls), 450,100 teachers, 157,200 head teachers, 1836 supervisory staff and 310 administrators along with 104 districts of four provinces, constituted the population of the study.

Twenty five districts from all over Pakistan were selected randomly. Fifty government primary schools (twenty five boys and twenty five girls) were taken from each district. Fifty heads, one hundred teachers (male and female), one hundred and four male supervisory staff and administrators and seventy five female supervisory staff and administrators were randomly selected from the sample institutions.

Three questionnaires were developed and administered on the following clusters of sample: Teachers, Head Teachers, Supervisory staff and Administrators. Moreover, National Education Policies, Development Plans, other official documents and research reports were analyzed. The analysis of data is presented in the following tables:

Table 1

Govt. primary schools supervisory staff and administrators (male and female) are satisfied with the quality of primary education.

\begin{tabular}{|c|c|c|c|c|c|c|c|}
\hline Responses & SA & AG & UD & DA & SD & Total & $\boldsymbol{x}^{\mathbf{2}}$ \\
\hline Male & 2 & 43 & 8 & 48 & 3 & 104 & $104.10^{*}$ \\
\hline Female & 3 & 30 & 8 & 29 & 5 & 75 & $51.65^{*}$ \\
\hline
\end{tabular}

* Significant $\quad \mathrm{df}=4 \quad$ Table value of $x^{2}$ at 0.05 level=9.49

Legend: SA: Strongly Agreed AG: Agreed UD: Undecided DA: Disagreed SD: Strongly Disagreed 
Table 1 indicates that calculated value of $x^{2}$ was found to be significant at 0.05 level in both. The trend of responses of supervisory staff and administrators was on 'disagree'. Hence, the statement, "Govt. primary schools supervisory staff and administrators (male and female) are satisfied with the quality of primary education" is negatively accepted.

Table 2

Govt. primary school teachers (male and female) opine that primary school curriculum is urban oriented.

\begin{tabular}{|c|c|c|c|c|c|}
\hline Responses & Mostly & To some extent & Not at all & Total & $\boldsymbol{x}^{\mathbf{2}}$ \\
\hline Male & 720 & 469 & 61 & 1250 & $531.00^{*}$ \\
\hline Female & 734 & 479 & 37 & 1250 & $596.96^{*}$ \\
\hline * Significant & $\mathrm{df}=2$ & \multicolumn{5}{|c|}{ Table value of $x^{2}$ at .05 level $=5.99$}
\end{tabular}

Table 2 illustrates that calculated value of $x^{2}$ was found to be significant at 0.05 level in both cases. The trend of responses (both male and female) was on 'mostly'. Therefore, the statement, "Govt. primary school teachers (male and female) opine that primary school curriculum is "urban oriented" is accepted.

Table 3

Govt. primary school heads (male and female) were provided training regarding revised curricula.

\begin{tabular}{|c|c|c|c|c|c|}
\hline Responses & Mostly & To some extent & Not at all & Total & $\boldsymbol{x}^{\mathbf{2}}$ \\
\hline Male & 58 & 162 & 405 & 625 & $304.40^{*}$ \\
\hline Female & 59 & 139 & 427 & 625 & $359.63 *$ \\
\hline * Significant & $\mathrm{df}=2$ & Table value of $x^{2}$ at 0.05 level $=5.99$
\end{tabular}

Table 3 shows that calculated value of $x^{2}$ was found to be significant at 0.05 level in both cases. The trend of responses of heads (both male and female) was on 'not at all'. Hence, the statement, "Govt. primary school heads (male and female) were provided training regarding revised curricula" is negatively accepted.

\section{CONCLUSIONS}

In the light of the analysis of data and findings of the study, these conclusions were drawn.

An extensive analysis based on theoretical evidence and data reflected the fact that the objectives of primary education were not fully achieved. The objective of universal, compulsory primary education and adoption of uniform curricula were not achieved. The main objectives of the policies and plans regarding primary education were universal, free and compulsory primary education, reduce dropouts and increase enrolment, improve quality of education, availability of physical facilities, community involvement, revision of curriculum, training of teachers and reform examination system. Further objectives stated in National Education Policy 1998 - 2010 were to integrate primary and middle level education into elementary education, enhance gross participation rate and retention rate, reduce disparities, uniform curricula and encourage private sector.

It was evident that education policies and plans were not implemented in letter and spirit. The New Education Policy 1970 and National Education Policy 1992 were not implemented. The Fourth Five Year Plan (1970 - 75) was also not implemented.

It was also observed that the procedure of implementation remained weak. Primary and middle education was integrated into elementary education but only 1550 schools were integrated into elementary schools against the target of 30,000 by the year 2002-03. The gross participation rate was enhanced 86 percent in 2004-05 against the target of 90 percent by the year 2002-03. Disparities were reduced to some extent. Retention rate was enhanced to 61 percent in 2004-05. It was also observed that Compulsory Primary Education Act was not promulgated in letter and spirit. However, the number of primary schools increased from 8413 to 157,200 . The enrolment increased from $7,70,000$ to $21,333,000$. The number of teachers increased from 17,800 to 450,100 . Participation rate increased from 
17 percent to 89 percent in 2004-05 (Govt. of Pakistan, 1992; Govt. of Pakistan, 2006). This indeed was a sizeable expansion but still many children in 5-9 age groups were found to be out of school.

Findings of the study revealed considerable improvements over the period of time. The improvements were mostly on quantitative side. Historically, the government had tried to expand primary education by establishing schools, but its qualitative improvement was ignored. Although, all the policies and plans emphasized to improve the quality of education but none of them could termed successful in making a break-through in this direction. It was evident from the data and discussion that the supervisory staff and administrators were not satisfied with the quality of primary education.

A curriculum is needed to attain the policy objectives. The study showed that the curriculum was difficult and urban oriented. Although the quality of textbooks was improved, many mistakes were still to be found both in content and presentation. Some concepts were presented in such a way that it was not possible for the students to comprehend them. However, Primary education was made free of cost. Books were also being provided free of cost. The span of primary education was extended by 5 to 6 years.

The teacher is the pivot of the entire educational system. Entry qualification for primary school teacher was raised from Matric to Intermediate and BA. The incentives and accountability system for teachers was improved. Service structure of teachers was revised. In-service training was provided to the teachers but training regarding revised curricula was not provided. It was observed that training needs were not assessed systematically through consultation with teachers.

Evaluation of pupil's learning requires the use of a number of techniques. Assessment is a technique for measuring learner's achievements. Therefore, National Education Assessment System (NEAS) was established.

\section{DISCUSSION}

Primary education is a prerequisite for acquiring further education. It yields higher social and economic returns when compared to secondary education. Unfortunately, it did not achieve desired level in Pakistan. Many policies and plans were formulated since independence. It was observed that the objectives of policies and plans regarding primary education were not fully achieved. Ghafoor (1982) viewed that the policies were ambitious and unrealistic. Bhatti et al (1986) analyzed that educational policies assigned priority to universalization of primary education. The targets fixed by the policies make interesting reading as we went on shifting these targets to longer periods. The targets were either too idealistic or the struggle for their achievement too inadequate.

It was observed that policies and plans were not implemented in letter and spirit. When it was discussed with administrators, they opined that the centralization in decision making, lack of finance, lack of political commitment, and non-availability of data affected the implementation process. Although, the National Education Council was established in 1982 to keep an eye on the implementation of educational programmes but the procedure of implementation remained weak and unsatisfactory. Khawaja (1985) pointed out that the policies were well reflected but implementation remained a major shortcoming. Many of their objectives never went beyond the paper.

Access to quality education is the basic right of every citizen. It was observed that majority of the supervisory staff and administrators were not satisfied with the quality of primary education. When it was discussed with administrative staff, they viewed that the students of government schools had poor performance in public examination as compared to the students of private schools. Mukhtar (1999) analyzed that learning achievements had been low in primary school education in Pakistan. Ahmer (2003) noted that despite tall claims by policy makers, no qualitative change had taken place in the field of education.

Curriculum is prepared to achieve the policy objectives and teacher is the main source of its implementation. After discussion, it was evident that government primary school teachers and heads were not involved in curriculum development and they found the curriculum difficult and urban oriented. Shah (1992) noted that teachers were not involved in curriculum development and curriculum was imposed on the teachers for 
execution. Govt. of Pakistan (1983) observed that curriculum was mostly urban-oriented. Choudhry (1992) further observed that curricula were invariably irrelevant to the needs of the rural communities.

Effective teaching demands that besides possessing adequate knowledge, teachers are required to undergo the training after the revision of curricula. It was observed that in-service training was provided to the teachers but the training regarding revised curricula was not provided. Moreover, training needs were not assessed systematically through consultation with teachers. Sheikh (2000) scrutinized that there was no in-depth training needs assessment of trainers and teachers to serve as a basis of course designing and selection of materials, methods, and evaluation techniques.

Evaluation is an important component of the instructional process. The performance of the students is measured through their assessment results only. Therefore, National Education Assessment System was established in 2003. Three assessments were held in a year. Progression in the primary classes was automatic up-to class 4th. All the student of class 5 had to appear in the compulsory public examination.

Educational policies are framed with a view to provide equal opportunities to all citizens of Pakistan. Despite the fact that Pakistan succeeded only in the partial realization of the policy objectives, there was still substantial qualitative expansion of primary education. The increase in the number of primary schools and the significant increase in students' enrolment are strong indicators that the government is addressing its educational issues. New initiatives, such as free primary education, free textbooks, and incentive for girl students are a sure sign that Government of Pakistan is serious in trying to achieve its educational objectives, as described in the policies and plans. These objectives can only be achieved if everyone in the education system realizes that the needs of the children must always come first, as they are the future of the Nation.

\section{ABOUT THE AUTHOR}

Ms. Shahida Parveen is principal of Angelic Public Girls Higher Secondary School, Jauharabad, District Khushab, Pakistan. She has completed her Ph.D. Education from University Institute of Education and Research, Pir Mehr Ali Shah Agriculture University, Rawalpindi, Pakistan. She served as a lecturer, at Raees-ul-Ahrar College of Education, Mirpur, Azad Jammu and Kashmir in 1995-96. She has presented many papers in Seminars. She has been serving as President, Vice President and Member of many Community Welfare Organizations since 1983. Her poetry has been publishing since 1984. She has got many Best Achievement Awards from the government as well as non-government organizations.

\section{REFERENCES}

1. Ahmed, M. Q. 1989. The Discrepancies in the Government Policies and Their Influence on Set Targets, A Case Study of Sixth Five Year Plan, Education Sector, Discussion Paper No 105. Reprint of: Pakistan Economic and Social Review. Applied Economic Research Centre. University of Karachi. May, 1989. Karachi. pp 6-7.

2. Ahmer, M. 2003. Mafias and Education. In Daily The News. $25^{\text {th }}$ November, 2003. Lahore.

3. Aziz, M. A. 1986. Review of Educational Policies and Corresponding Five Year Plans (1947-1986). National Development Group. APEID. Planning Wing. Ministry of Education, Islamabad. 1p.

4. Bhatti, M, M. Afazal, M. Nadeem, H. Khalid, B. Hashmi and S. Shireen. 1986. Primary Education Improvement: Desired Measures. Educational Development Series: 1. National Education Council, Islamabad. pp 2-3.

5. Chaudhary, R. 1992. Importance and Need of Literacy and Basic Education for National Development. Literacy in Pakistan. In: Literacy and Basic Education in Pakistan (Report of the Seminar). National Education and Training Commission in Collaboration with UNICEF, Islamabad. 59p.

6. Ghafoor, A. 1982. Occassioanl Papers in Educational Planning, Management and Facilities. UNESCO, Bangkok, pp. 13-14.

7. Govt. of Pakistan. 1947. Proceeding of the Pakistan Education Conference. Ministry of Interior. Education Division, Karachi. pp. 20-22. 
8. Govt. of Pakistan. 1956. The First Five Year Plan. 1955-60. Planning Board, Karachi. pp. $397-398$.

9. Govt. of Pakistan. (1959). Report of the Commission on National Education. (pp.170-185). Karachi: Ministry of Education.

10. Govt. of Pakistan. 1960a. The Second Five Year Plan. 1960-65. Planning Commission, Karachi. pp. 337345 .

11. Govt. of Pakistan. 1960b. Report of the Commission on National Education. Ministry of Education, Karachi. pp. 170-185.

12. Govt. of Pakistan. 1965. The Third Five Year Plan. 1965-70. Planning Commission, Karachi. pp. $185-209$.

13. Govt. of Pakistan. 1966. Report of the Commission on Student Problems and Welfare. Ministry of Education. Government of Pakistan Press, Karachi. 25p.

14. Govt. of Pakistan. 1970b. Economic Survey of Pakistan. Economic Affairs Wing. Finance Division, Islamabad. pp 251-255

15. Govt. of Pakistan. 1972. The Education Policy. 1972-80. Ministry of Education, Islamabad. pp. 1-33.

16. Govt. of Pakistan. 1976. Economic Survey of Pakistan. Economic Affairs Wing. Finance Division, Islamabad. 197p

17. Govt. of Pakistan. 1977. Economic Survey of Pakistan. Economic Affairs Wing. Finance Division, Islamabad. pp 202-210

18. Govt. of Pakistan. 1978a. The Fifth Five Year Plan. 1978-83. Planning Commission, Karachi. pp. $307-340$.

19. Govt. of Pakistan. 1978b. Economic Survey of Pakistan. Economic Affairs Wing. Finance Division, Islamabad. pp 162-166

20. Govt. of Pakistan. 1979. National Education Policy and Implementation Programme, Ministry of Education, Islamabad. pp. 5-67.

21. Govt. of Pakistan. 1980. Economic Survey of Pakistan. Economic Affairs Wing. Finance Division, Islamabad. pp 197-202

22. Govt. of Pakistan. 1981. Economic Survey of Pakistan. Economic Affairs Wing. Finance Division, Islamabad. pp 200-205

23. Govt. of Pakistan. 1983. The Sixth Five Year Plan. 1983-88. Planning Commission, Islamabad. pp. 383-392.

24. Govt. of Pakistan. 1988. The Seventh Five Year Plan. 1988-93. Planning Commission, Islamabad. pp. $243-$ 253.

25. Govt. of Pakistan. 1993a. The Eighth Five Year Plan. 1993-98. Planning Commission, Islamabad. pp. 297316.

26. Govt. of Pakistan. 1994. Economic Survey of Pakistan. Economic Affairs Wing. Finance Division, Islamabad. pp 107-108

27. Govt. of Pakistan. 1996. Economic Survey of Pakistan. Economic Affairs Wing. Finance Division, Islamabad. pp 111-115

28. Govt. of Pakistan. 1998a. National Education Policy. 1998-2010. Ministry of Education, Islamabad. pp. 1101.

29. Govt. of Pakistan. 1998b. The Ninth Five Year Plan. 1998-2003. Planning Commission, Islamabad. pp. 128.

30. Govt. of Pakistan. 1998c. Economic Survey of Pakistan. Economic Affairs Wing. Finance Division, Islamabad. pp 121-126

31. Govt. of Pakistan. 1999. Economic Survey of Pakistan. Economic Affairs Wing. Finance Division, Islamabad. pp 111-117

32. Govt. of Pakistan. 2000. Pakistan Economic Survey 1999-2000. Finance Division, Economic Adviser's Wing, Islamabad. pp. 140-144.

33. Govt. of Pakistan. 2001. Economic Survey of Pakistan. Economic Affairs Wing. Finance Division, Islamabad. pp 150-160

34. Govt. of Pakistan. 2002. Pakistan Economic Survey 2001-02. Finance Division, Economic Adviser's Wing, Islamabad. pp. 146-153.

35. Govt. of Pakistan. 2003. Economic Survey of Pakistan. Economic Affairs Wing. Finance Division, Islamabad. pp 159-166 
36. Govt. of Pakistan. 2005. Economic Survey of Pakistan. Economic Affairs Wing. Finance Division, Islamabad. pp 139-148

37. Govt. of Pakistan. 2006. Pakistan Economic Survey 2005- 06. Government of Pakistan. Finance Division, Economic Adviser's Wing, Islamabad. 160p.

38. Jabeen, F. 1990. An Evaluation of the Planning Strategies for Education in Pakistan. 1947-89. Unpublished Thesis. University of the Punjab, Lahore. pp.1-195.

39. Khawaja, S. 1985. Perspective for Educational Development in Pakistan. Seminar for Senior Educational Administrators on Education Policies and Plans. Academy of Educational Planning and Management. Ministry of Education, Islamabad. pp. 27-28.

40. Mukhtar, E. 1999. Basic Education in Pakistan. UNESCO, Islamabad. 28 p.

41. Shah, G.A., Minister of Education, Forward, in: National Education Policy 1998-2010, Islamabad, Ministry of Education, March 27, 1998, Vp.

42. Shah, M. 1992. Staff Development for Secondary Teachers in Pakistan. Unpublished M.A. Thesis. School of Education. University of Bristol, Bristol. 43p.

\section{NOTES}


NOTES 